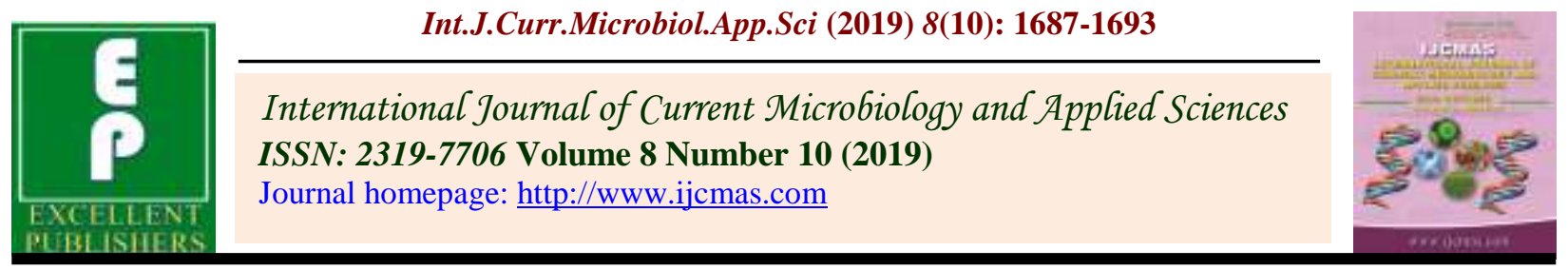

Original Research Article

https://doi.org/10.20546/ijcmas.2019.810.196

\title{
Effect of Integrated Nitrogen Management on growth and Fodder Yield of Sweet Sorghum [Sorghum bicolor (L.) Moench]
}

\author{
Peter Paul and Rajesh Singh* \\ Department of Agronomy, SHUATS, Prayagraj, India \\ *Corresponding author
}

\section{A B S T R A C T}

\section{Keywords}

Integrated nitrogen

management,

Growth, Green

fodder,

Vermicompost,

Poultry manure

\section{Article Info}

Accepted:

12 September 2019

Available Online:

10 October 2019
A field experiment was conducted during the kharif season 2018 at the Crop Research Farm, Department of Agronomy, Naini Agricultural Institute, SHUATS, Prayagraj (U.P.) to study effect of integrated nitrogen management on growth and fodder yield of sweet sorghum [Sorghum bicolor (L.) Moench] crop. The soil of the experimental field was sandy loam with organic carbon $(0.45 \%)$ and a soil $\mathrm{pH}$ of 7.2 . The experiment was laid out in a randomized block design consisting of 13 treatments replicated thrice. Treatments consisted of control, 3 levels of inorganic sources of nitrogen viz., $\mathrm{N}_{1}(80 \%), \mathrm{N}_{2}(60 \%)$ and $\mathrm{N}_{3}(40 \%)$ and 4 organic sources of nitrogen viz., Poultry Manure, Vermicompost, Poultry Manure + Azospirilum (Seed Inoculation) and Vermicompost + Azospirilum (Seed Inoculation) with their levels viz., Poultry Manure $(20 \% \mathrm{~N}, 40 \% \mathrm{~N}$ and $60 \% \mathrm{~N})$ and Vermicompost $(20 \% \mathrm{~N}, 40 \% \mathrm{~N}$ and $60 \% \mathrm{~N})$. The result revealed that treatment $\mathrm{T}_{4}-[80 \%$ RDN through inorganic source $+20 \% \mathrm{~N}$ through V.C + Azospirillum (Seed inoculation)] recorded significantly higher plant height $(152.77 \mathrm{~cm})$ at 75 DAS, dry weight $(99.23 \mathrm{~g})$ at 75 DAS, no. of leaves per plant (12.27) at 75 DAS, leaf area index (3.63) at 75 DAS and green fodder yield $(41.33 \mathrm{t} / \mathrm{ha})$ whereas crop growth rate $(0.48)$ at $60-75 \mathrm{DAS}$ was found significantly higher in treatment $\mathrm{T}_{10}(40 \% \mathrm{RDN}$ through inorganic source $+60 \% \mathrm{~N}$ through vermicompost). However, relative growth rate at 60-75 DAS was found to be nonsignificant.

\section{Introduction}

Sweet sorghum (Sorghum bicolor (L.) Moench), the genus Sorghum belongs to the tribe Andropogoneae of the family Poaceae. Sweet sorghum and the other cultivated species have a chromosome number of $n=10$ and primarily self-pollinated with about 2 to 5 $\%$ cross pollination. Most valuable traits present are high green matter yield (up to $65 \mathrm{t}$ $\mathrm{ha}^{-1}$ ), large lodging resistance, high content of soluble sugars, and drought tolerance. Sweet sorghum is one of the most important cereals for global agriculture.

Considering crop area, it is the fifth cereal species after wheat, rice, maize and barley, but is mainly cultivated in semi-arid and arid regions of the world (Borghi et al., 2013) cultivated in about $5.82 \mathrm{~m}$ ha area with a 
production of $5.39 \mathrm{mt}$. Sweet sorghum has been widely cultivated in the U.S since the 1850 for use in sweeteners, primarily in the form of sorghum syrup annually. Making syrup from sorghum (as from sugarcane) is heavily labour-insensitive.

The success of livestock industry depends on feeding the animals with sufficient quantity of nutritious forage to meet their requirements for maintenance, growth and production. At present, India has nearly $40 \%$ short supply of green forage production.

Sweet sorghum is a special type of forage sorghum, which has the ability to accumulate fermentable sugars (15-17\%) in its stalk.

It is the only crop which provides green fodder, grain and stem that can be used for chewing, sugar, alcohol, syrup, jaggery, roofing, fencing and paper manufacturing. Nitrogen is the most important nutrient element, while sorghum is known to respond well to $\mathrm{N}$ fertilization.

There are a number of studies reporting on positive effect of nitrogen application on yields of grain sorghum and forage sorghum.

In contrast relatively few studies have been made regarding the effect of $\mathrm{N}$ on sweet sorghum productivity.

Application of organic manures along with inorganic fertilizers into the soil increases the productivity of plants and also sustained the soil health for longer period (Gawai and Pawar, 2007)

\section{Materials and Methods}

A field experiment was conducted during the Kharif season of 2018 on sweet sorghum at Crop Research Farm, Department of Agronomy, Naini Agricultural Institute,
SHUATS, Prayagraj (U.P.), which is located at $25^{\circ} 57^{\prime} \mathrm{N}$ latitude, $87^{0} 50^{\prime} \mathrm{E}$ longitude and at an altitude of $98 \mathrm{~m}$ above the mean sea level. The soil of experimental field was sandy loam having $\mathrm{pH}$ of 7.2 with $0.45 \%$ organic carbon, available nitrogen $225 \mathrm{~kg} \mathrm{ha}{ }^{-1}$, available phosphorus $19.50 \mathrm{~kg} \mathrm{ha}^{-1}$, and available potassium $92.00 \mathrm{~kg} \mathrm{ha}^{-1}$.

The experiment was laid out in randomized block design with thirteen treatments replicated thrice. Treatments consisted of control, 3 levels of inorganic sources of nitrogen viz., $\mathrm{N}_{1}(80 \%), \mathrm{N}_{2}(60 \%)$ and $\mathrm{N}_{3}$ $(40 \%)$ and 4 organic sources of nitrogen viz., Poultry Manure, Vermicompost, Poultry Manure + Azospirilum (Seed Inoculation) and Vermicompost + Azospirilum (Seed Inoculation) with their levels viz., Poultry Manure $(20 \% \mathrm{~N}, 40 \% \mathrm{~N}$ and $60 \% \mathrm{~N})$ and Vermicompost $(20 \% \mathrm{~N}, 40 \% \mathrm{~N}$ and $60 \% \mathrm{~N})$. Azospirillum spp was used as biofertilizer for seed inoculation in sweet sorghum crop.

The recommended dose of $\mathrm{N}, \mathrm{P}, \mathrm{K}$ for sweet sorghum was 120:50:50 kg/ha. The required amount of vermicompost, poultry manure was calculated and applied with respect to the treatments. Urea, single super phosphate and murate of potash were used as inorganic sources for nitrogen, phosphorus and potassium respectively.

\section{Results and Discussion}

\section{Plant height}

The data pertaining to plant height is presented in Table 1. At 75 DAS, the plant height was found to be significantly higher in treatment $\mathrm{T}_{4}[80 \%$ RDN through inorganic source $+20 \% \mathrm{~N}$ through V.C + Azospirillum (Seed inoculation)] $(152.77 \mathrm{~cm})$ whereas treatment $\mathrm{T}_{1}(80 \%$ RDN through inorganic source $+20 \% \mathrm{~N}$ through Poultry Manure) and treatment $\mathrm{T}_{2}(80 \%$ RDN through inorganic 
source $+20 \% \mathrm{~N}$ through Vermicompost) were found to be statistically at par with treatment $\mathrm{T}_{4}$. The plant height is the main growth character that could be influenced to great extent by management practices. Similar results were reported by Hugar et al., (2010).

\section{No of leaves per plant}

The data related to No of leaves per plant is presented in Table 1 which revealed that, at 75 DAS the no. of leaves per plant was found to be significantly higher in treatment $\mathrm{T}_{4}[80 \%$ RDN through inorganic source $+20 \% \mathrm{~N}$ through V.C+ Azospirillum (Seed inoculation)] (12.27) whereas treatment $\mathrm{T}_{10}$ (40\% RDN through inorganic source $+60 \% \mathrm{~N}$ through vermicompost) and treatment $\mathrm{T}_{9}(40 \%$ RDN through inorganic source $+60 \% \mathrm{~N}$ through Poultry Manure) were found to be statistically at par with treatment $\mathrm{T}_{4}$.

Increase in nitrogen level might have resulted in more active plant growth, which consecutively resulted in more dry matter partitioning. Similar results were reported by Yadav et al., (2007), Singh et al., (2005).

\section{Dry weight}

The data related to Dry weight is presented in Table 1. At 75 DAS, the dry weight was found to be significantly higher in treatment $\mathrm{T}_{4}[80 \%$ RDN through inorganic source $+20 \% \mathrm{~N}$ through V.C+ Azospirillum (Seed inoculation)] (99.23g) whereas treatment $\mathrm{T}_{2}$ (80\% RDN through inorganic source $+20 \% \mathrm{~N}$ through Vermicompost) and treatment $\mathrm{T}_{3}$ [80\%RDN through inorganic source $+20 \% \mathrm{~N}$ through Poultry Manure + Azospirillum (seed inoculation)] were found to be statistically at par with treatment $\mathrm{T}_{4}$.

Higher accumulation of nutrient contents is attributable for significant increase in total dry mater (Ghosh et al., 2004).

\section{Leaf area index}

The data related to Leaf area index is presented in the Table 1, at 75 DAS the leaf area index was found to be significantly higher in treatment $\mathrm{T}_{4}(80 \% \mathrm{RDN}$ through inorganic source $+20 \% \mathrm{~N}$ through V.C + Azospirillum (seed inoculation)] (3.63) whereas the treatment $\mathrm{T}_{8}[60 \% \mathrm{RDN}$ through inorganic source $+40 \% \mathrm{~N}$ through V.C + Azospirillum (Seed inoculation)] and treatment $\mathrm{T}_{3}[(80 \%$ RDN through inorganic source + $20 \% \mathrm{~N}$ through P.M + Azospirillum (seed inoculantion)] were found to be statistically at par with treatment $\mathrm{T}_{4}$. However, integration of organics with fertilizers showed significant differences than sole one and also increase in LAI was observed with rate of fertilizers application. The results were in conformity with Patil (2007).

\section{Crop growth rate}

The data related to Crop growth rate is presented in the Table 1. At 60-70 DAS Crop growth rate was found to be significantly higher in treatment $\mathrm{T}_{10}(40 \%$ RDN through inorganic source $+60 \% \mathrm{~N}$ through vermicompost) (0.48) whereas treatment $\mathrm{T}_{7}$ [60\% RDN through inorganic source $+40 \% \mathrm{~N}$ through P.M + Azospirillum (Seed inoculation)] and treatment $\mathrm{T}_{12}(40 \% \mathrm{RDN}$ through inorganic source $+60 \% \mathrm{~N}$ through V.C + Azospirillum (seed inoculation)] were found to be statistically at par with treatment $\mathrm{T}_{10}$.

\section{Relative growth rate}

The data related to Relative Growth Rate was presented in Table 1. At 60-75 DAS, Relative growth rate was found to be non-significant. It was found to be highest in treatment $\mathrm{T}_{10}(40 \%$ RDN through inorganic source $+60 \% \mathrm{~N}$ through vermicompost) (0.008). 
Table.1 Effect of integrated nitrogen management on growth attributes of sweet sorghum

\begin{tabular}{|c|c|c|c|c|c|c|c|}
\hline S.No. & Treatments & $\begin{array}{c}\text { Plant Height } \\
\text { at } 75 \text { DAS } \\
(\mathrm{cm})\end{array}$ & $\begin{array}{c}\text { Dry weight } \\
\text { at } 75 \text { DAS } \\
\text { (g) }\end{array}$ & $\begin{array}{c}\text { No. of leaves } \\
\text { per plant } \\
\text { at } 75 \text { DAS }\end{array}$ & $\begin{array}{c}\text { Leaf Area } \\
\text { Index at } \\
75 \text { DAS }\end{array}$ & $\begin{array}{c}\text { CGR } \\
\left(\text { g m }^{-2} \text { day }^{-1}\right) \\
\text { 60-75 DAS }\end{array}$ & $\begin{array}{c}\text { RGR } \\
\left(\mathrm{g} \mathrm{g}^{-1} \text { day }^{-1}\right) \\
\text { 60-75 DAS }\end{array}$ \\
\hline & & & & & & & \\
\hline 1. & $\begin{array}{l}80 \% \text { RDN through inorganic source }+20 \% \mathrm{~N} \text { through } \\
\text { Poultry Manure }\end{array}$ & 151.67 & 97.64 & 10.93 & 2.81 & 0.432 & 0.006 \\
\hline 2. & $\begin{array}{c}80 \% \text { RDN through inorganic source }+20 \% \mathrm{~N} \text { through Vermi } \\
\text { compost }\end{array}$ & 151.13 & 98.69 & 10.53 & 2.97 & 0.407 & 0.006 \\
\hline 3. & $\begin{array}{l}80 \% \mathrm{RDN} \text { through inorganic source }+20 \% \mathrm{~N} \text { through Poultry } \\
\text { Manure }+ \text { Azospirillum (seed inoculation) }\end{array}$ & 148.67 & 98.63 & 11.04 & 3.22 & 0.308 & 0.004 \\
\hline 4. & $\begin{array}{l}80 \% \text { RDN through inorganic source }+20 \% \mathrm{~N} \text { through Vermi } \\
\text { compost }+ \text { Azospirillum (Seed inoculation) }\end{array}$ & 152.77 & 99.23 & 12.27 & 3.63 & 0.350 & 0.005 \\
\hline 5. & $\begin{array}{l}60 \% \text { RDN through inorganic source }+40 \% \text { N through Poultry } \\
\text { Manure }\end{array}$ & 145.93 & 96.28 & 10.67 & 3.11 & 0.434 & 0.007 \\
\hline 6. & $\begin{array}{c}60 \% \text { RDN through inorganic source }+40 \% \mathrm{~N} \text { through Vermi } \\
\text { compost }\end{array}$ & 146.87 & 93.87 & 10.73 & 2.90 & 0.408 & 0.006 \\
\hline 7. & $\begin{array}{c}60 \% \text { RDN through inorganic source }+40 \% \mathrm{~N} \text { through Poultry } \\
\text { Manure }+ \text { Azospirillum (Seed inoculation) }\end{array}$ & 146.10 & 93.90 & 10.33 & 2.91 & 0.446 & 0.007 \\
\hline 8. & $\begin{array}{l}60 \% \text { RDN through inorganic source }+40 \% \mathrm{~N} \text { through Vermi } \\
\text { compost }+ \text { Azospirillum (Seed inoculation) }\end{array}$ & 135.10 & 93.92 & 11.13 & 3.39 & 0.317 & 0.005 \\
\hline 9. & $\begin{array}{l}\text { 40\% RDN through inorganic source }+60 \% \mathrm{~N} \text { through Poultry } \\
\text { manure }\end{array}$ & 136.07 & 92.63 & 12.07 & 2.81 & 0.258 & 0.004 \\
\hline 10. & $\begin{array}{c}40 \% \text { RDN through inorganic source }+60 \% \mathrm{~N} \text { through Vermi } \\
\text { compost }\end{array}$ & 135.73 & 90.97 & 11.17 & 3.12 & 0.484 & 0.008 \\
\hline 11. & $\begin{array}{l}40 \% \text { RDN through inorganic source }+60 \% \mathrm{~N} \text { through } \\
\text { Poultry manure }+ \text { Azospirillum (Seed inoculation) }\end{array}$ & 147.33 & 96.05 & 10.87 & 2.99 & 0.339 & 0.005 \\
\hline 12. & $\begin{array}{l}40 \% \text { RDN through inorganic source }+60 \% \mathrm{~N} \text { through Vermi } \\
\text { compost }+ \text { Azospirillum (Seed inoculation) }\end{array}$ & 136.10 & 93.27 & 11.33 & 2.85 & 0.435 & 0.007 \\
\hline \multirow[t]{4}{*}{13.} & $100 \% \mathrm{~N}$ through inorganic source(control) & 135.07 & 68.67 & 10.07 & 2.61 & 0.278 & 0.006 \\
\hline & F test & NS & $\mathrm{S}$ & $\mathrm{S}$ & $\mathrm{S}$ & $\mathrm{S}$ & NS \\
\hline & SEm \pm & 5.09 & 1.61 & 0.34 & 0.17 & 0.051 & 0.0075 \\
\hline & $\mathrm{CD}(\mathrm{P}=0.05)$ & - & 4.71 & 1.02 & 0.49 & 0.145 & - \\
\hline
\end{tabular}


Table.2 Effect of integrated nitrogen management on fodder yield of sweet sorghum

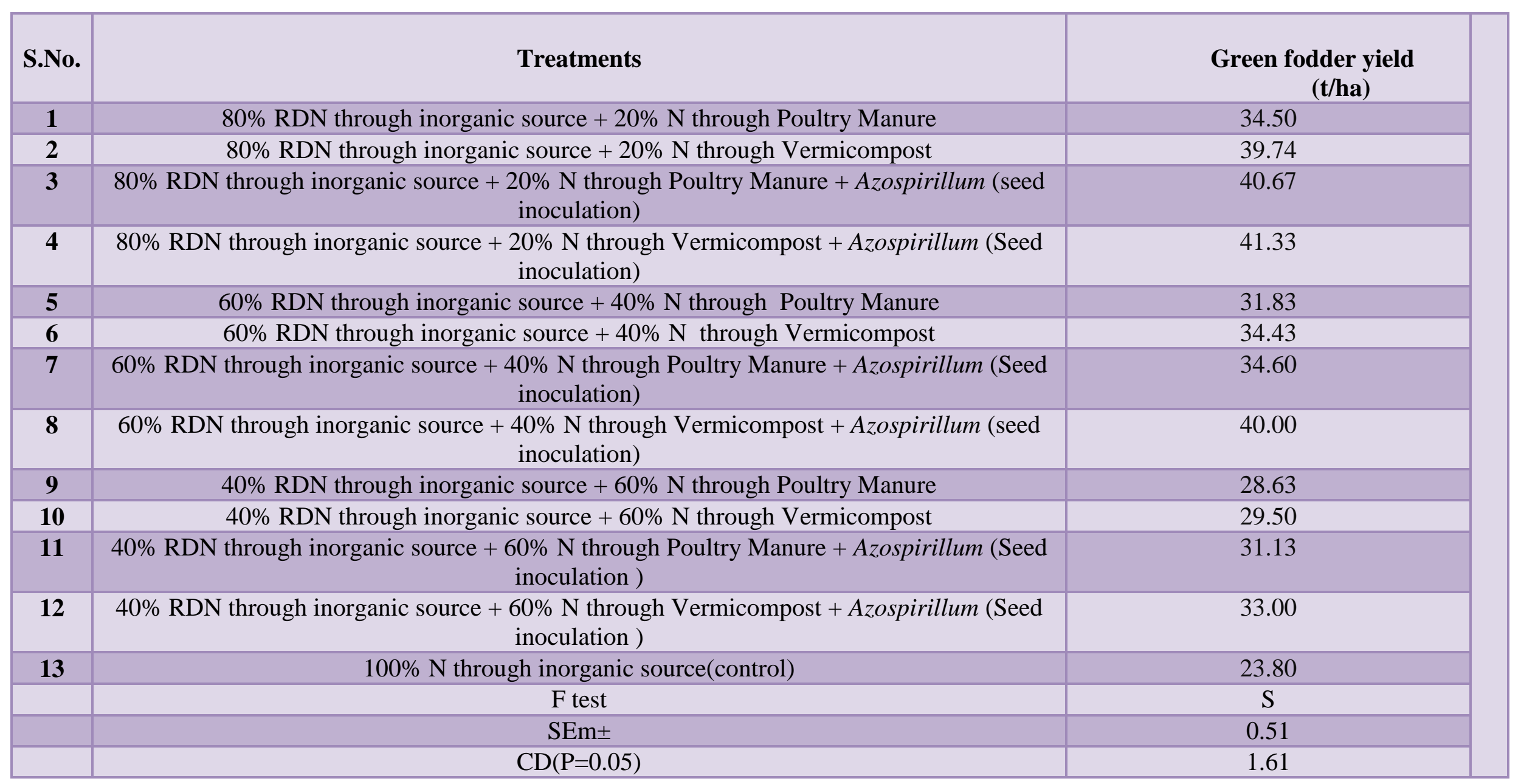




\section{Green fodder yield}

The data pertaining to green fodder yield is presented in Table 2, which revealed that the green fodder yield $(41.33 \mathrm{t} / \mathrm{ha}$ ) was found to be significantly higher with the treatment $\mathrm{T}_{4}$ [80\% RDN through inorganic source $+20 \% \mathrm{~N}$ through V.C + Azospirillum (Seed inoculation) whereas treatment $\mathrm{T}_{3}[80 \%$ RDN through inorganic source $+20 \% \mathrm{~N}$ through Poultry Manure + Azospirillum (Seed inoculation)] and $\mathrm{T}_{8}[40 \%$ RDN through inorganic source + $60 \% \mathrm{~N}$ through V.C + Azospirillum (Seed inoculation) were found to be statistically at par with treatment $\mathrm{T}_{4}$.

The reason for higher forage yield was that, the higher $\mathrm{N}$ received by plants may be attributed to the most lucrative consumption of applied nitrogen and other allied environmental by forage sorghum crop which resulted in maximum biomass yield. Increase in forage yield with increased nitrogen was mainly associated with greater plant height, higher number of leaves plant $^{-1}$ and stem diameter. The lower application of $\mathrm{N}$ level $\left(50 \%\right.$ of RDF $\left.\mathrm{ha}^{-1}\right)$ significantly decreased forage weight $(\mathrm{g})$ plant $^{-1}$, forage production day $^{-1}$ and forage yield $\left(\mathrm{t} \mathrm{ha}^{-1}\right)$ because of significant reduction in yield attributes. These results are in conformity with Karwasra and Anil Kumar (2006), Verma et al., (2005).

Based on the findings, of this experiment it can be concluded that application of $80 \%$ nitrogen through urea and $20 \%$ nitrogen through vermicompost alongwith seed inoculation of azospirilum was found economically profitable for farmers.

\section{References}

Borghi E, Crusciol CAC, Nascente AS, Sousa VV, Martins PO, Mateus GP, Costa C. 2013. Sorghum grain yield, forage biomass production and revenue as affected by intercropping time. European Journal of Agronomy 51: 130-139.

Gawai, P.P. and Pawar, V.S. 2007. Yield and yield components of sorghum (Sorghum bicolor L.).As influenced by Integrated Nutrient Management system and its residual effect on chickpea (Cicer arietinum L.) Ann.Agric.Res.Newseries. 26(3): 378382.

Ghosh, P.K., Ajay, Bandyopadhyay, K.K., Manna, M.C., Mandal, K.G., Mishra, A.K. and Hati, K.M. 2004. Comparative effectiveness of cattle manure, poultry manure, phosphocompost and fertilizer NPK on three cropping systems in vertisol of semi- arid tropic. II. Drymatter yield, nodulation, chlorophyll content and enzyme activity. Bioresource Technology 95: 85-93.

Hugar, A.Y., Jayadeva, H.M., Rangaswamy, B.R., Shivanna, S and Chandrappa, H. 2010. Assessing the effect of nitrogen and harvesting stages on yield and yield attributes of sweet sorghum (Sorghum bicolor (L.) Moench) genotypes. Agriculture Science Digest 30(2): 139-141.

Karwasara, R. S. and Anil Kumar 2006. Effect of nitrogen and phosphorus on fodder sorghum production. Haryana Journal of Agronomy 22(1): 24-25.

Patil, V.L 2007. Effect of farm yard manure FYM nitrogen and trap crops on striga incidence, growth and yield of kharif sorghum (sorghum bicolor (L) Moench). M.Sc. Thesis submitted to university of Agricultural Sciences, Dharwad, India.

Singh, M.M., Maurya, M.L., Singh, S.P. and Mishra, C.H. 2005. Effect of nitrogen level and biofertilizer inoculation on productivity of forage sorghum (Sorghum bicolor). Indian Journal of 
Agricultural Science 75(3): 167-168. Yadav, P.C., Sadhu, A.C. and Swarnkar, P.K. 2007. Yield and quality of multi-cut forage sorghum (Sorghum sudanese) as influenced by integrated nitrogen management. Indian Journal of Agronomy 52(4): 330-334.
Verma, S.S., Navneet Singh, Joshi, Y.P. and Vijay Deorari 2005. Effect of nitrogen and zinc on growth characters, herbage yield, nutrient uptake and quality of fodder sorghum (Sorghum bicolor). Indian Journal of Agronomy 50(2): 167-169.

\section{How to cite this article:}

Peter Paul and Rajesh Singh. 2019. Effect of Integrated Nitrogen Management on Growth and Fodder Yield of Sweet Sorghum [Sorghum bicolor (L.) Moench]. Int.J.Curr.Microbiol.App.Sci. 8(10): 1687-1693. doi: https://doi.org/10.20546/ijcmas.2019.810.196 